the spring 2013 issue of the Hudson Review, devoted to ecology once again after so many years, I take the occasion to quote Morgan's keen statement of the relevance of the environment to literature and the arts before turning to my own reflections on "ecocriticism at twenty-five." As Waage intimates, putative landmark dates are merely convenient markers, less accurate than they seem. All I had in mind by "twentyfive" was to associate what we now think of as an academic mainstreaming of ecocriticism with the aftereffects of the 1991 MLA session, the establishment of ASLE and ISLE, and the influence of my and Glotfelty's The Ecocriticism Reader: Landmarks in Literary Ecology.

Harold Fromm

Institute of the Environment University of Arizona, Tucson

\section{Historicism and Unhistoricism in Queer Studies}

\section{To THE EDITOR:}

Valerie Traub's “The New Unhistoricism in Queer Studies" (128.1 [2013]: 21-39) invokes Marx's Communist Manifesto, but in her reading it is not communism that haunts Europe but teleology that haunts queer studies. Perhaps, then, teleologists should openly, before the world, publish their views, their aims, their tendencies, and meet this nursery tale of the specter of teleology with a manifesto of the party itself!

But rather than a manifesto in defense of teleology, what ensues is a complaint about the degree to which antiteleologists purportedly malign as unqueer those who periodize and historicize. Traub denounces the antiteleologists' critique as opposition to history itself, thus suggesting that history is teleology, period.

I am not an antiteleologist. I have a strong theory of teleology: I call it mortality. This is how I practice what Traub calls an "enhanced discernment of the ways our bodies remain in time" (36); indeed, I frequently refer to myself in print as a "future dead person" ("Theorizing Queer Temporalities: A Roundtable Discussion" [Queer Temporalities; ed. Elizabeth Freeman; spec. issue of GLQ 13.2-3 (2007): 177-95; print; 184]). "A teleological perspective views the present as a necessary outcome of the past," Traub writes, though this perspective may equally comprehend the ends to which we are all tending (21). Apocalypse is also a teleological model, and perhaps when apocalyptic outcomes dominate the teleological discourse of the day, some LGBTQ scholars feel moved to explore temporality's queerness, to find in time a way "out," or at least another way. This may well be how some of us "contend with the irreducible force of time's movement on our bodies, our species, and the planet," in part because the contending goes hand in hand with an acute awareness of our relative incapacities to do so (32).

Both mournful and celebratory queer twistings of time have been emerging from decades of mortality's untimely reign in LGBTQ communities. Some of these writings explore the affective experience of temporality as recursive or even repetitive; some chart nostalgia's backward-looking melancholy; some trace temporality's effects in and as the present; and some celebrate the sheer queerness of nonprogressive time. But all fashion ways of thinking about how time-that strange measure of our mortal lives-impresses itself upon us subjectively and collectively. This is to discuss a temporality that is precisely not history, though history itself, either as "experienced" or as "narrated," has varying phenomenal temporalities and is, as well, subjective, insofar as there must be either a subject to experience or a narrator to narrate.

So, when Traub says that readings "are not the same thing as history" (30), I agree, and with acclaim, but add that history-insofar as "we" have access to it-presents itself as a reading. Fredric Jameson (historicist par excellence) writes, "History is not a text, for it is fundamentally non-narrative and nonrepresentational; what can be added, however, is 
the proviso that history is inaccessible to us except in textual form, or in other words, that it can be approached only by way of prior (re)textualization" (The Political Unconscious: Narrative as a Socially Symbolic Act [Cornell UP, 1981; print; 82]). Indeed it is Jameson, and not I, who marks history as a limit to the queer playfulness of phantasmic investments, in his famous statement "History is what hurts, it is what refuses desire and sets inexorable limits to individual as well as collective praxis" (102). It would seem that Traub agrees, and yet she also wants history to be a domain of potential queer play (no quarrel here).

Let me take a moment to summarize for readers what my argument actually was in "Undoing the Histories of Homosexuality," the chapter in Queer/Early/Modern that criticizes David Halperin's How to Do the History of Homosexuality, because I believe it was respectful, careful, and historical-though not only historical, since I also take seriously the literariness or "counterfactual" status of texts we call fiction (Duke UP, 2006; print; 31-50). My critique involved a short story by Boccaccio that has been richly analyzed by a number of younger scholars, such as Susan Gaylard, in "The Crisis of Word and Deed in Decameron V 10" (The Italian Novella, ed. Gloria Allaire [Routledge, 2003; 33-48; print]), and Martin G. Eisner and Marc D. Schachter, in "Libido Sciendi: Apuleius, Boccaccio, and the Study of the History of Sexuality" (PMLA 124.3 [2009]: 817-37; print). Whereas Halperin was using the text to deduce a protohomosexual identity in fourteenthcentury Italy, I wanted to cast doubt on the empirical and historical status of a description located in a text that flamboyantly showcases its counterfactual nature. I also extended Eve Kosofsky Sedgwick's critique of an earlier work by Halperin, primarily concerning not universalizing and minoritizing models but rather narratives of supersession: to taxonomize identities as pre- or protohomosexual presumes something called "modern homosexuality" and potentially relegates to the past the modalities of same-sex desire that do not adhere to that model, while simultaneously homogenizing and globalizing a "modern" homosexual identity. So what I was offering was a critique less of historicizing than of promoting progressivist and potentially Eurocentric models of historical change and identity-not because they are historical, as Traub asserts, but because they are ideological.

Traub concludes, as she begins, by invoking another specter, one who "bequeath[s]" a copia and generates a legacy, and she worries that that legacy will become diluted (36). Is this the specter of the essay's opening paragraph, the one who is both an insubstantial shade and a vision of the future? Is it the specter of Hamlet? And if time is out of joint, must someone set it right? Traub's essay is itself, it seems to me, a work of mourning enjoining readers to honor the past; it thus has its own kind of queer temporality. But-or and-the queerest thing is that the storm keeps blowing us backward ... into the future.

Carla Freccero

University of California, Santa Cruz

\section{To THE EDITOR:}

In response to Valerie Traub's essay "The New Unhistoricism in Queer Studies," I would like to propose ten theses on queer (un)historicism:

1. With so much to learn from dialogue and debate, with so much to be gained by taking the challenges to both historicism and unhistoricism seriously, as Traub proposes to do, it is disappointing that her essay remains so firmly entrenched in oppositionality. Traub's work on the confluence of psychoanalysis and historicism-two supposedly warring methodologies-has been important for queer Renaissance work, so it is particularly distressing to see camps being created where none need exist.

2. Positing unhistoricism as the opposite of historicism merely repeats the binary logic 